\title{
Academic Self Concept and Academic Achievement of Secondary School Students
}

\author{
Sandeep Kumar Jaiswal ${ }^{1, *}$, Rashmi Choudhuri ${ }^{2}$ \\ ${ }^{1}$ Research Scholar, Faculty of Education, Banaras Hindu University, Varanasi, Uttar Pradesh, India \\ ${ }^{2}$ Professor, Faculty of Education, Banaras Hindu University, Varanasi, Uttar Pradesh, India \\ *Corresponding author: snadeepmns1989@gmail.com
}

\begin{abstract}
At the level of secondary school, student's self-concept about their academic capabilities plays an important role. The aims of the study were to examine the relationship between academic self-concept and academic achievement of secondary students and to compare the academic self-concept of male and female secondary students. Sample of the study were 615 secondary school students of both genders (Male 317, Female 298, aged 14-17 years). The sample was drawn from 15 secondary schools affiliated with CBSE board, session 2016-17 of Varanasi city, India. Academic achievement was measured by self-reported Cumulative Grade Point Average (CGPA) of the previous year. Academic self-concept was measured using Kample and Naik (2013) Academic Self Concept Scale (ASCS), which was composed of 57 items, distributed in 8 subscales namely Academic Ability, Academic Interests, Study, Examination, Academic Interaction, Academic Efforts, Curriculum, and Academic Future. The result of the study revealed that there was a positive relationship between academic self-concept and academic achievement and this relationship was stronger for female students $(r=.28)$ than that of male students $(r=.17)$. Moreover, gender differences in the academic self-concept of the students were also found. Female students had significantly higher academic self-concept than male students.
\end{abstract}

Keywords: academic self-concept, academic achievement, secondary students

Cite This Article: Sandeep Kumar Jaiswal, and Rashmi Choudhuri, “Academic Self Concept and Academic Achievement of Secondary School Students." American Journal of Educational Research, vol. 5, no. 10 (2017): 1108-1113. doi: 10.12691/education-5-10-13.

\section{Introduction}

A great deal of research work on self-concept has been done in India and abroad but the work on the academic self-concept is very less. Academic self-concept refers students' attitude, perception, and enjoyment of subject or class lecture in school. Students' self-perception plays an important role to adjust themselves in school during childhood and adolescence and directing the students' efforts towards their academic works. The multi-dimensional model of self-concept show that an academic self is one of the important facets of self that contribute to an individuals' global self-concept, together with social, emotional, and physical self-concept [1,2,3]. The construct of self-concept is derived from self-worth theory [4]. Self-concept is generally defined as an individual's perception based on self-knowledge or experience and formed through interaction with environment and attributes of his or her behavior [5]. Academic self-concept is conceived as a student's self-perception regarding specific academic domains or abilities [6]. This multidimensional model of self-concept refers an important distinction between general self-concept which includes cognitive, affective, and behavioral aspects whereas academic self-concept refers to an individual's perception of their academic competence $[7,8]$. Cokley [9] has defined academic self-concept as a student's view of his or her academic ability when compared with other students. Whereas Byrne and Shavelson [1] defined academic self-concept as involving a description and an evaluation of one's perceived academic competence. In a more comprehensive way Lent et. al. [10] have explained the academic self-concept as specific attitude, feeling and perceptions about one's intellectual or academic skills representing a person's self-beliefs and self-feeling regarding the academic setting.

Researches and multiple sources of empirical data show that for doing well academically, beginning with a positive self-concept is an important prerequisite $[1,12]$. Students with positive self-concept tend to reflect socially acceptable behaviors. Researchers have also supported that academic self-concept is developed through process of social comparison, which comes into place when students compare their ability with others [13]. The stage of secondary school level or adolescence is usually a period of developmental transition which an individual passes from childhood to maturity. During this transition, adolescents face so much psychological and sociological pressure in their life. They face psychological maturation, cognitive changes, sifting of societal and parental expectations, conflicting role demands, complexity in relation with parents and peers, choice of school and subject and adjustment in the school environment. Despite of all these changes, adolescence is also characterized as a 
time of evaluation of self and subsequent reformation of perceptions [14].

In this context it becomes imperative to investigate the level of academic self-concept of secondary school students and its relationship with academic achievement of students. As such to have a better understanding of Indian adolescent, the present study will be important to understand the academic self of secondary level students and its relationship with academic achievement.

\section{Studies on Academic Self Concept and Academic Achievement}

Researchers agree that self-concept is an important prerequisite for performing well in education. In this account several studies have shown a positive relationship between academic self-concept and academic achievement $[15,16,17]$. Moreover, studies have also been conducted to determine the direction of causal relationship between academic self-concept and academic achievement. Literatures show that there are three models to determine the direction of the relationship between academic self-concept and academic achievement as (i) self enhancement model (ii) skill development model (iii) reciprocal effect model.

The self enhancement model proposed that academic self-concept is a determinant of academic achievement. The supporters of self enhancement model claim that academic self-concept is a primary cause of academic achievement, that means academic self-concept foster the academic achievement $[3,18,19]$. In contrast to this, in the model of skill development, academic self-concept is a consequence of academic achievement. The supporter of this model claim that the past achievement influences the formation of academic self-concept but academic self-concept does not improve academic achievement [20,21,22]. An examination of these two models generated controversy among the researchers that which model is correct and from this controversy emerged the reciprocal effect model. According to reciprocal effect model, academic self-concept and academic achievement have a reciprocal effect and they mutually reinforce each other [21,22]. The reciprocal effect model assumed that improvement in academic achievement would lead to the better academic self-concept and improved academic self-concept would reinforce to better academic achievement. According to Liu [23], students who have scored less academic achievement would develop the lower positive academic belief and confidence, which in the end would develop lower academic self-concept. On the other hand, low level of academic self-concept will decrease the learning motivation, and interest which would result in poor academic performance. In a study Guay et. al. [24] concluded that students who keep positive attitude toward their academic ability obtained higher grades because their positive academic self-concept reinforce them to be more autonomously motivated in school or in class room.

As literatures show, most of the research studies have demonstrated theoretical and empirical support for the reciprocal effects model $[22,25]$. In a longitudinal study on $10^{\text {th }}$ grade students in U.S. public high schools Marsh \& O'Mara [26] examined the reciprocal effects among academic self-concept, self-esteem, academic achievement and educational attainment. Result was consistent with reciprocal model and showed positive reciprocal effects between academic self-concept and academic achievement. Study of Marsh [27] supported the self enhancement model and reported that GPA in class $11^{\text {th }}$ and $12^{\text {th }}$ were significantly affected by academic self-concept whereas the previously attainted grade did not play any measurable effect on academic self-concept. In another longitudinal study on $7^{\text {th }}$ grade students, Marsh et. al. [12] investigated the reciprocal effect on standardized test score and interest. Result showed that the effect of prior academic selfconcept had significant effect on grades, standardized test scores, and interest in math.

Most of the studies clearly indicated a positive relationship between academic self-concept and academic achievement. However, there are also some evidences regarding no or statistically non-measurable correlation between academic self-concept and academic achievement. Trusty et. al. [28] conducted a study on African American elementary students $(\mathrm{N}=563)$ and found no correlation between school related self-concept and achievement test scores. Similarly, Areepatiamannil and Freeman [29] found moderate correlation between academic self-concept and achievement of secondary school students.

Research studies also indicated that as students grow older their academic self-concept becomes weaker and more stable [21,30,31]. Several studies on gender differences have reported that male and female have different academic self-concept [32,33,34]. In a study Kling et. al. [35] reported that male have higher academic self-concept than female. Similarly, Lau [33] conducted a study on Hong Kong adolescents. Result show that both genders' academic self-concept decreased from grade 7 to grade 9 , but decrease rate was greater for female students. On the other hand, Lau [33] reported that from grade 9 onwards the academic self-concept of both genders was increased and this increase was greater for the male students. After conducting a comprehensive review of literature, it was found that the relationship between academic self-concept and academic achievement is well established outside India. Such researches are needed in Indian context too. In the light of all these empirical evidences and rationale, the investigator has aimed to achieve the following objectives.

Objectives of the study:

1. To study the academic self-concept of secondary school students.

2. To study the relationship between academic self-concept and academic achievement of secondary school students.

3. To compare the academic self-concept of male and female secondary school students.

\section{Method}

This study was quantitative in nature and descriptive survey method was applied to achieve the objective of the study.

\subsection{Participants}

The sample for the present study was drawn from 15 secondary schools affiliated with CBSE Board, session 
2016-17, of Varanasi city, Uttar Pradesh, India. Only class $\mathrm{X}$ students were selected as participants of the study. Participants were 317 male and 297 female students, who were ranged in age from 14 to 17 years. The sample was obtained through multi stage random sampling. The schools were considered as a cluster and randomly selected from all the CBSE board affiliated secondary schools of Varanasi city. In each selected school, there were several sections of class $\mathrm{X}$ and among these one section was selected randomly. All the students of randomly selected classes were considered as a cluster, and formed the final sample of the study.

\subsection{Measures}

\subsubsection{Academic Self Concept}

To measure the academic self-concept of secondary school students, the Academic Self Concept Scale (ASCS) developed by Kample and Naik [34] was used. ASCS consisted of 57 items, distributed in 8 sub scales namely Academic Ability (9), Academic Interests (5), Study (11), Examination (7), Academic Interaction (10), Academic Efforts (5), Curriculum (6), and Academic Future (5) and Cronbach's alpha estimate of reliability for these sub scale is $0.86,0.92,0.88,0.84,0.870 .90,0.85,0.87$ respectively. The responses for each item were given on 5point Likert type and the value ranged from 5 (strongly Agree) to 1 (strongly disagree) according to the positive and negative items. The Cronbach's alpha estimate of reliability for the total scale is 0.93 which is good and acceptable in social science research situation.

\subsubsection{Academic Achievement}

To measure the academic achievement of the secondary school students, their previous year (class IX) Cumulative Grade Point Average (CGPA) score was taken and considered as the measurement of academic achievement.

\subsection{Procedure}

The data gathering process was begun by visiting each of the selected schools. First of all, the investigator contacted the principals and talked to them about the purpose of visit and the brief introduction of the research work. After taking the permission of the principal, investigator went to the respective class and ensured that students were seated properly. The investigator distributed the tool to all the students and provided a brief orientation to them regarding purpose of data collection and how to show response on the tool. After ensuring that students were confident and have no any doubt they were instructed to fill ASCS, which was attached with the demographic information sheet. Investigator also clarified now and then, if any queries could be asked by the students. The collected data was analyzed and presented as the result of this study.

\section{Result}

This section deals with the results according to the objectives of the study. To compare the mean and find out the relationship between variables, t-test and bivariate product moment correlation ' $r$ ' were computed respectively by using IBM SPSS 20.0.

\subsection{Academic Self-Concept of Secondary School Students}

The academic self-concept of the students was measured as a mean of total score on Academic Self Concept Scale (ASCS) obtained by the individuals. On the basis of quartile-1 and quartile-3, the norms were developed by the investigators to infer the status of secondary students' academic self-concept. Q3 and above range (225 and above) show high ASCS, between Q1 and Q3 range (197-225) show average ASCS while below Q1 range (below 197) show low ASCS.

Table 1. Mean, SD and Status of Academic Self Concept of secondary school students

\begin{tabular}{|c|c|c|c|c|}
\hline Students & N & Mean & SD & Status \\
\hline Overall & 615 & 211.09 & 19.11 & Average \\
\hline Male & 317 & 209.32 & 18.88 & Average \\
\hline Female & 298 & 212.97 & 19.20 & Average \\
\hline
\end{tabular}

It was seen from Table 1 that mean of secondary school students on Academic self-concept scale was 211.09 (SD, 19.11) which means that the level of academic selfconcept of secondary school students was average according to the norms. Table 1 also shows the male students' (M 209.32, SD 18.88) and female students' (M 212, SD 19.20) academic self-concept, which was also average level for both the genders.

Table 2. Distribution of students according to the level of Academic Self Concept

\begin{tabular}{|c|c|c|c|}
\hline $\begin{array}{c}\text { Range of Score (based } \\
\text { on Q3 and Q1) }\end{array}$ & $\begin{array}{c}\text { No. of } \\
\text { students }\end{array}$ & Percentage & Description \\
\hline 225 and above & 162 & $26.34 \%$ & High ASCS \\
\hline 197 to 225 & 307 & $49.92 \%$ & Average ASCS \\
\hline Below 197 & 146 & $23.74 \%$ & Low ASCS \\
\hline
\end{tabular}

It was seen from the Table 2 that $26.34 \%$ students had high academic self-concept and $49.92 \%$ students had average academic self-concept whereas only $23.74 \%$ students had low academic self-concept. Therefore, it can be concluded that most of the secondary school students $(49,92 \%)$ had average academic self-concept.

\subsection{Relationship between Academic Self-concept and Academic Achievement}

To find out correlation between secondary students' academic self-concept and academic achievement, the bivariate correlation coefficient has been used and tested at 0.05 level of significance.

$\mathbf{H}_{\mathbf{R}}$ : There is significant relationship between secondary students' academic self-concept and academic achievement.

Table 3. Show the correlation between Academic Self Concept (ASC) and Academic Achievement (AA) of secondary school students

\begin{tabular}{|c|c|c|c|}
\hline Students & $\mathrm{N}$ & Correlation & Sig. (2-tailed) \\
\hline Overall & 615 & .23 & $\mathrm{P}<.01$ \\
\hline Male & 317 & .17 & $\mathrm{P}<.01$ \\
\hline Female & 298 & .28 & $\mathrm{P}<.01$ \\
\hline
\end{tabular}


Table 3 shows that the correlation between academic self-concept and academic achievement of secondary school students was positive $(\mathrm{r}=.23)$ and significant at 0.05 level of significance. It was also significant at 0.01 level of significance. Moreover, this relationship was also significantly positive for both male and female students at 0.05 and 0.01 level of significance. Here investigator found an important fact that the correlation was stronger for female students $(\mathrm{r}=.28)$ than that of male students $(\mathrm{r}=.17)$.

\subsection{Regression Analysis Predicting Academic Achievement}

To determine the extent to which academic self-concept contribute on the prediction of Academic Achievement, linear regression $($ Method= Enter) was used.

Table 4. Linear Regression Analysis Predicting Academic Achievement $(\mathrm{N}=615)$

\begin{tabular}{|c|c|c|c|c|c|c|}
\hline \multicolumn{7}{|c|}{ Model Summary $^{\mathbf{b}}$} \\
\hline Model & $\mathrm{R}$ & $\begin{array}{c}\mathrm{R} \\
\text { Square }\end{array}$ & $\begin{array}{c}\text { Adjusted } \\
\text { R Square }\end{array}$ & $\begin{array}{c}\text { Standardized } \\
\text { Coefficients } \\
\text { (Beta) }\end{array}$ & $\mathrm{F}$ & sig \\
\hline 1 & $.230^{\mathrm{a}}$ & .053 & .051 & 1.425 & 34.23 & $\mathrm{P}<.01$ \\
\hline
\end{tabular}

a. Predictors: (Constant), ASCS

b. Dependent Variable: CGPA.

As seen in the Table 4, the result indicated that the model was statistically significant $(\mathrm{F}=34.23, \mathrm{P}<.01$, $\left.\mathrm{R}^{2}=.051\right)$. Academic self-concept accounted for $5.1 \%$ of the variance in the CGPA that students received. This finding suggests that students performed academically better when they had good level of academic self-concept.

\subsection{Comparison of Academic Self-concept}

To compare the academic self-concept of male and female students, mean difference was calculated. Further in order to check the significance of this difference, $\mathrm{t}$-value was also calculated and tested at 0.05 level of significance.

$\mathbf{H}_{\mathbf{R}}$ : Male and Female secondary students do not differ in terms of mean scores on academic self-concept.

Table 5. Show the comparison between Academic self-concept of Male and Female secondary school students

\begin{tabular}{|c|c|c|c|c|c|c|c|}
\hline Gender & $\mathrm{N}$ & Mean & S.D. & $\begin{array}{c}\text { Mean } \\
\text { Difference }\end{array}$ & $\mathrm{df}$ & t-value & $\begin{array}{c}\text { Sig. } \\
(2 \text {-tailed })\end{array}$ \\
\hline Male & 317 & 209.32 & 18.88 & \multirow{2}{*}{3.65} & 613 & 2.38 & $\mathrm{P}<.01$ \\
\hline Female & 298 & 212.97 & 19.20 & & & & \\
\hline
\end{tabular}

Table 5 shows that at $613 \mathrm{df}$; and 0.05 and 0.01 level of significant, the calculated $t-$ value $(t=2.38)$ was significant so null hypothesis was rejected. Therefore, it was inferred that there was significant difference between male and female secondary students' mean score of academic self-concept. Further, Table 5 show that the mean score of female $(\mathrm{M}=212.97)$ was greater than the mean score of male students $(M=209.32)$. Hence it is concluded that female students had significantly higher academic self-concept than the male students.

\section{Discussion}

The results of the study reveal that secondary school students have average level of academic self-concept. Moreover, it is seen that most of the students (49.92\%) have average level of academic self-concept, whereas $26.34 \%$ students show high academic self-concept and $23.74 \%$ students had low academic self-concept. The percentage distribution of students in all three groups shows that the participants of the present study are normally distributed on academic self-concept. The finding of this study is much similar with the finding of Marsh et. al. [37], Marsh [32] and Lau [33] studies which reported that, students hold average level of academic self-concept at secondary school level.

The result of the present study shows a positive and significant relationship $(\mathrm{r}=.23, \mathrm{p}>.01)$ between academic self-concept and academic achievement of secondary school students. This is corroborated by the findings of Reynolds [15], Tan \& Yates [38], Marsh [39] and Cokley [9] that have shown a positive and significant relationship between academic self-concept and academic achievement in their respective studies. The positive and significant relationship between academic self-concept and academic achievement as found in Indian adolescent students of secondary level was also found adolescent students in western countries such as Canada [30] and Germany $[12,40]$ and Asian countries such as China [41] and Hong Kong [42]. The present study supports the view that students' positive belief about their capabilities and academic competence are important to be successful in their educational achievement. The present finding underscores the importance that how students positively feel about their academic ability, effort, academic interest and curriculum to be successful in their educational programs.

Comparison of the academic self-concept of male students and female students in the present study revealed a significant difference between the academic self-concept of male students and female students. It means that both male and female students at secondary level were not same in the view they hold about their academic belief and capabilities. Findings of earlier research studies like Marsh [32], Lau [33], and Ireson \& Hallam [35] are in line with the result of the present study that female students have higher academic self-concept than male students. Also, at the same time this result shows contradiction with the finding of Kling et. al. [36] who reported that the male students had a higher academic self-concept than female students. The finding of the present study refutes the finding of the study done by Hossaini [43] which revealed that gender does not influence the self-concept and self-concept does not play any significant role to influence academic achievement. Perhaps, the differences in academic self-concept of male and female students are due to the fact that they differ in their respective concerns. Adolescent girls are more concerned about being well liked, are more affected by others' opinion about them, have commitment and belief in hard work while boys place more importance on the intrinsic motivation of feeling intelligent, high confidence in their intelligent and ability when they look at their academic competence 
$[44,45]$. It was also to be noted that female students had relatively higher mean score for CGPA $(\mathrm{N}=298, \mathrm{M}=7.82)$ than their male counterparts $(\mathrm{N}=317, \mathrm{M}=7.62)$. Again, female students' academic self-concept was found to be higher than the male students. On the basis of this finding it can be implied that higher academic self-concept is accompanied with higher academic achievement. Therefore, it can be concluded that academic self-concept is positively related to academic achievement. This finding supports the self enhancement model which claims that academic self-concept is a prerequisite to enhance academic achievement $[18,25,46]$. If students perceived themselves as academically competent and positive belief about their effort, then they can obtain higher grades because their academic self-concept will motivate the students autonomously at school.

\section{Conclusion}

The result of the present study concludes that there was a positive relationship between academic self-concept and academic achievement of students at secondary school level. Further this study also concluded that there was difference between the academic self-concept of male and female students at secondary school level. Researchers suggest that formation of academic self-concept depend upon the process of social comparison which comes into action as students compare their ability with others [13]. If teachers work only to improve students' academic achievement without fostering students' self-belief in their academic capabilities, then the achievement gains will not be long lasting. On the other hand, if teachers foster academic self-concept without working on the way to enhance the positive academic achievement then the gains in self-concept will likely to be short lived. In simple way, improved academic achievement will lead to better academic self-concept and good academic self-concept will lead to better academic achievement. If teachers focus either only on academic self-concept or academic achievement then both are likely to suffer. Academic self-concept is also composed of the social, emotional and physical dimensions $[47,48]$. Therefore, it becomes imperative for parents also that they should emotionally attach with their adolescents and also facilitate the social development and physical requirements related with academic need. Hence, this study suggests that, teachers and parents should strive to improve simultaneously both academic self-concept and academic achievement to ensure long lasting and positive development of students' academic outcomes.

\section{References}

[1] Byrne, B. M., \& Shavelson, R. J. (1986). On the structure of adolescent self-concept. Journal of Educational Psychology, 78, 474-481.

[2] Marsh, H. W., Byrne, B. M., \& Shavelson, R. (1988). A multifaceted academic self-concept: its hierarchical structure and its relation to academic achievement. Journal of Educational Psychology, 80, 366-380.

[3] Marsh, H. W. (2005). Self-concept theory, measurement and research into practice: the role of self-concept in educational psychology. Leicester, UK: Education Section of the British Psychological Society.
[4] Marsh, H. W., \& Shavelson, R. J. (1985). Self-concept: Its multifaceted, hierarchical structure. Educational Psychologist, 20, 107-125.

[5] Eccles, J. S. (2005). Studying the development of learning and task motivation. Learning and Instruction, 15, 161-171.

[6] Trautwein, U., Ludtke, O., Koller, O., \&Baumert, J. (2006). Selfesteem, academic self concept, and achievement: How the learning environment moderates the dynamics of self concept. Journal of Personality and Social Psychology, 90, 334-349.

[7] Bandura, A. (1993). Perceived self-efficacy in cognitive development and functioning. Educational Psychologist, 28, 117-148.

[8] Ireson,J.,\&Hallam, S. (2009). Academic self-concepts in adolescence: Relations with achievement and ability grouping in schools. Learning and Instruction.19 (2009). 201-213.

[9] Cokley, K. (2000). An investigation of academic self-concept and its relationship to Academic achievement in African American college students. Journal of Black Psychology, 26, 148-164.

[10] Lent, R. W., Brown, S. D., \& Gore, P. A., Jr. (1997). Discriminant and predictive validity of academic self-concept, academic selfefficacy, and mathematics specific self-efficacy. Journal of Counselling Psychology, 44(3), 307-315.

[11] Hamachek, D. (1995). Self-concept and school achievement: Interaction dynamics and a tool for assessing the self-concept component. Journal of Counselling and Development, 73(4), 419-425.

[12] Marsh, W. H., Trautwein, U., Ludtke, O., Koller, O., Baumert, J. (2005). Academic self-concept, interest, grades, and standardized test scores: Reciprocal effects models of causal ordering. Child Development, 76(2), 397- 416.

[13] Marsh, H. W., \& Parker, J. (1984). Determinants of student self-concept: is it better to be a relatively large fish in a small pond even if you don't learn to swim as well? Journal of Personality and Social Psychology, 47, 213-231.

[14] Block, J., \& Robins, R. W. (1993). A longitudinal study of consistency and change in self-esteem from early adolescence to early adulthood. Child Development, 64, 909-923.

[15] Reynolds, W. M. (1988). Measurement of academic self-concept in college students. Journal of Personality Assessment, 52, 223-240.

[16] Marsh, H. W., \& Shavelson, R. J. (1985). Self-concept: Its multifaceted, hierarchical structure. Educational Psychologist, 20, 107-125.

[17] DeDonno, M.A., Fagan, J.F. (2013). The Influence of Family Attributes on College Students' Academic Self-concept. North American Journal of Psychology, 15, (1), 49-62.

[18] Green, J., Nelson, G., Martin, A.J., \& Marsh, H. (2006). The causal ordering of self-concept and academic motivation and its effect on academic achievement. International Education Journal, 7(4), 534-546.

[19] Valentine, J. C., DuBois, D. L., \& Cooper, H. (2004). The relations between self-beliefs and academic achievement: A systematic review. Educational Psychologist, 39, 111-133.

[20] Jen, T.H., \& Chien, C.C. (2008). The Influence of the academic self-concept on academic achievement: from a perspective of learning motivation. Conference Proceedings of IRC.

[21] Marsh, H. W., Ellis, L., \& Craven, R. G. (2002). How do preschool children feel about themselves? Unravelling measurement and multidimensional self-concept structure. Developmental Psychology, 38, 376-393.

[22] Marsh, H. W., \& Craven, R. G. (2006). Reciprocal effects of selfconcept and performance from a multidimensional perspective: Beyond seductive pleasure and unidimensional perspectives. Perspectives on Psychological Science, 1, 133-163.

[23] Liu, Hui-Ju (2009). Exploring changes in academic self-concept in ability grouped English classes. chang gung. Journal of Humanities and Social Sciences, 2(2), 411-432.

[24] Guay, F., Chanal, J., Ratelle, C. F., Marsh, H. W., Larose, S., \&Boivin, M. (2010). Intrinsic, identified, and controlled types of motivation for school subjects in young elementary school children. British Journal of Educational Psychology, 80, 711-735.

[25] Marsh, H. W., \& Martin, A. J. (2011). Academic self-concept and academic achievement: Relations and causal ordering. British Journal of Educational Psychology, 81, 59-77.

[26] Marsh, H. W., \& O`Mara, A. J. (2008). Reciprocal effects between academic self-concept, self-esteem, achievement, and attainment 
over seven adolescent years: Unidimensional and multidimensional perspectives of self-concept. Personality and Social Psychology Bulletin, 34, 542-552.

[27] Marsh, H.W. (1990). Causal ordering of academic self-concept and academic achievement: a multi-wave, longitudinal panel analysis. Journal of Educational Psychology, 82(4): 646-656.

[28] Trusty, J., Watts, R.E., \& House, G. (1996). Relationship between self-concept and achievement for African-American preadolescents. Journal of Humanistic Education and Development, (35), 29-39.

[29] Areepattamannil, S., \& Freeman, J.G. (2008). Academic achievement, academic self-concept, and academic motivation of immigrant adolescents in the Greater Toronto Area Secondary Schools. Journal of Advanced Academics, 19(4), 700-743.

[30] Guay, F., Marsh, H. W., \&Boivin, M. (2003). Academic self-concept and academic achievement: Developmental perspectives on their causal ordering. Journal of Educational Psychology, 95, $124-136$.

[31] Liu, W. C., \& Wang, C. K. J. (2005). Academic Self-Concept: A Cross-Sectional Study of Grade and Gender Differences in a Singapore Secondary School. Asia Pacific Education Review, 6(1), 20-27.

[32] Marsh, H. W. (1989). Age and sex effects in multiple dimensions of self-concept: Preadolescence to early adulthood. Journal of Educational Psychology, 81(3), 417-430.

[33] Lau, S. (1990). Crisis and vulnerability in adolescent development. Journal of Youth and Adolescence, 19(2), 111-131.

[34] Kamble, V.S., Naik, B.A. (2013). Manual of academic selfconcept scale. Prasad Psycho Corporation: New Delhi.

[35] Ireson, J., \& Hallam, S. (2001). Ability grouping in education. London: Chapman.

[36] Kling, K. C., Hyde, J. S., Showers, C. J., \& Buswell, B. N. (1999). Gender differences in self-esteem: A meta-analysis. Psychological Bulletin, 125, 470-500.

[37] Marsh, H. W., Parker, J., \& Barnes, J. (1985). Multidimensional adolescent self-concepts: Their relationship to age, sex an academic measures. American Educational Research Journal, 22(3), 422-444.

[38] Tan, J. B., \& Yates, S. M. (2007). A Rasch analysis of the Academic Self-Concept Questionnaire. International Educational Journal, 8(2), 470 - 484.
[39] Marsh, H. W. (2004). Negative effects of school-average achievement on academic self-concept: A comparison of the bigfish-little-pond effect across Australian states and territories. Australian Journal of Education, 48, 5-26.

[40] Marsh, H. W., \& Koller, O. (2003). Bringing together two theoretical models of relations between academic self-concept and achievement. In H. W. Marsh, R. G. Craven, \& D. McInerney (Eds.), International advances in self research (Vol. 1, pp. 17-45). Greenwich, CT: Information Age.

[41] Yeung, A. S., \& Lee, F. L. (1999). Self-concept of high school students in China: Confirmatory factor analysis of longitudinal data. Educational and Psychological Measurement, 59, 431-450.

[42] Marsh, H. W., Hau, K. T., \& Kong, C. T. (2002). Multilevel causal ordering of academic self-concept an achievement: Influence of language of instruction (English vs. Chinese) for Hong Kong students. American Educational Research Journal, 39 , 727-763.

[43] Hossaini, S. M. (2002). Forecasting between self-esteem, parenting and gender among pre-university of students in Shiraz. University of Shiraz, Shiraz, Iran.

[44] Lau, S., \& Leung, K. (1992). Relations with parents and school and Chinese adolescents' self-concept, delinquency, and academic performance. British Journal of Educational Psychology, 62, 193-202.

[45] Liu, W. C. (1994). Academic self-concept in a streamed setting: Home environment and classroom climate factors. Unpublished M.Ed. dissertation, University of Nottingham, England.

[46] Valentine, J. C., \& Dubois, D. L. (2005). Effects of self-beliefs on academic achievement and vice versa. Separating the chicken from the egg. In H. W. Marsh, R. G. Craven, \& D. M. McInerney (Eds.), International advances in self research: New frontiers for self research (Vol. 2, pp. 53-78). Greenwich, CT: Information Age.

[47] Lewis, J. D., \& Knight, H. V. (2000). Self-concept in gifted youth: An investigation employing the Piers-Harris subscales. Gifted Child Quarterly, 44, 45-53.

[48] Mui, F. L. L., Yeung, A. S., Low, R., \& Jin, P. (2000). Academic self-concept of talented students: Factor structure and applicability of the internal/external frame of reference model. Journal for the Education of the Gifted, 23, 343-367. 